\title{
ALINHAMENTO DE SORRISO POR MEIO DE RESINA COMPOSTA.
}

Bruno GUTIERRES, Margareth NUNES

Os dentes anteriores freqüentemente são acometidos pela desarmonia dental, defeitos estruturais, variações de cor e forma, comprometendo o sorriso. A realização de técnicas diretas com resina composta é uma alternativa que atinge ótimos resultados desde que bem indicada e bem executada. Propõe-se apresentar uma técnica direta com resina composta em dentes anteriores com alteração severa do alinhamento dental por meio de um caso clínico. A queixa do paciente consistiu na falta de estética de seu sorriso, pois apresentava alteração de posicionamento dos elementos dentários da bateria anterior, além da presença de várias restaurações insatisfatórias de classe III e $\checkmark$ e manchamento extrínseco generalizado. Ao exame clínico observou-se que os dentes 13, 21 e 23 apresentavam-se vestibularizados. O tratamento realizado consistiu na confecção de faceta direta com resina composta, para amenizar o alto grau de escurecimento dos dentes e a reconstrução das regiões de dentina e esmalte. Após o término da restauração pôde-se observar um excelente restabelecimento da forma, contorno e cor dos dentes envolvidos. O tratamento com facetas diretas de resina composta representa um método capaz de restabelecer a harmonia do sorriso, sendo ainda um procedimento mais conservativo quando comparado a preparos totais.

Palavras-chave: Maloclusão; Resina composta; Facetas dentárias. 